\title{
COMO FOMOS RECEBIDOS EM PORTUGAL
}

Temos o grato prazer de reproduzir e - ao mesmo tempo - de agradecer, os cmáveis cunceitos, para nós verdadeiramente estimuladores, que a revista Vértice, de Coimbra, publicou sôbre a Revista de História, no seu número 82 (vol. IX), pp. 374/375, de julho de 1950. Aqui reproduzimos o que nessa revista escreveu o Snr. Rui Feijó:

"Revista de História - ano $I, n .^{\circ} 1$ - Janeiro-março de 1950 - São Paulo. - Recebemos nai nossa redação o primeiro nủmero desta magnifica revista,-orgão da Faculdade de Letras ds: Universidadie de São Paulo, de que é diretor E. Simões de Paula, professor de História da Civilização Antiga e Medieval da Universidade daquela cidade. Da Comissãc de Redacção faz parte o nosso compatriota Fidelino de Figueiredo que na Universidade de São Paulo leciona Literatura Portuguêsa.

Dos seus objetivos dão bem idéia estas palavras do artigo de apresentaçāo da autoria do direter: "é oferecer acs estudiosos uma oportunidade de divulgação sistemática... dos trabalhes e pesquisas que $o$ amor ao estudo $e$ a dedicação ao trabalho propiciam e orientam"; e mais adiante: "Mas quer ter também. outra finalidade; quer ser o traço de união entre a: Faculdade e os professôres de História do ensino normal e secundário. Para isso pretende fornecer-lhes bibliografias sempre atualizades, interpretações novas de fatos históricos em geral, resenhas críticas de obras recentes, comentários desapaixcnados à margem de assuntos controvertidos e documentos antigos devidamente estudados". O que evidentemente implica uma ligação éntre a Faculdade e a Nação através dos professôres - fato de excepcional importância e pelo qual nesta revista sempre temos combatido.

Quanto as espírito que os anima, à compreensão que têm da história, basta que se diga que o diretor se reclema do conceito de história de Lucien Febvre de quem a revista publica uma notável conferência sôbre o "Homem do Sécuic XVI" que o célebre professor do Collège de France proferiu na Universidade de São Paulo. Notável trabalho êste do Prof. Lucien Febvre cuja lição profunda devia 
er bem meditada: o homem não é o mesmo no século XVI e no nosso tempo ; näo quer dizer que seja meihor ou piot - com isso não pense que se deve preocupar o histcriador pois todos os juizos que possa fazer são aferidos por uma moral que se demonstra nêo imutável; mas o homem do século XVI é completamente diferente do do século XX - na maneira de amar, de ser, de viver, no próprio desenvolvimento relativo dos sentidos então sobrelevando-se o ouvido, e hoje sendo mais desenvolvido 0 da vista. Este frto que só por si destrói muitas metafísicas, muitas tiradas sóbre o homem-absoluto é para nós portuguêses, de uma importanucia enorme, se considerarmos que a esta luz pão foi ainda vista a zossa história dêsse periodo glorioso. Mas não é só neste ponto que a conferência do Prof. Lucien Febvre é uma expléndida liçăo e só podemos aconselhar vivamente a todos a sua leitura.

Do sumário, televamos como mais importantes os seguirtes artigos: de M. E Austregésilo, "Pesquisas sôbre a existêncis do ouro e prata no Pianalto Paulista nos séculos XVI e XVII"; de A. Ellis Júnior sôbre o "Ciclo da Muar" einda o relato da defesa de tese do Dr. Lourival Gomes Machado para a cadeira da Política da Universidade de Sâo Paulo, Faculdade de Letras que versou sóbre o "Tratado de Direito Natura" de Tomaz Antônio Gonzaga e em qua se trataram problemas que interessam tanto à história da cultura do Brasil como de Portugal.

A uma täo prornetedora floração de estudos históricos (não esqueçamos que o Brasil tem historiadores e sociólogos de valor de Artur Ramos, Gilberto Freire e que lá sureiu Euclides da Cunha) não deve ser estranho o compreensivo intercámbio de professôres, pois na Universidade de Säo Paulo tem ensizado professôres estrangeiros de grande categoria. O nivel de uma publicação como esta deve-se, sem dúvida, à tradição dos estucios históricos to Brasil hoit brilhanteriente mantida por histcriadores e sociólogos de justo ienome, mas tambérn, ousamos adiantá-1o, ao espírito compreensivo que tem feito que homens como Braudel e Morazé hajam ensinado zas Faculdedes brasileiras, trazendo ds novas geraçóes o mais adiantado njvel de investigaçēo histórica.

A nova revista brasileira desejamos larga expansão em Pcrtugel, ume lenga vida e que ajude a realizar esse bela obra que em perte é comum às duas aacōes: a história àe Portuggl * do Bresil."

\section{E. SIMOEES DE. PALLA}

